\title{
BIODIVERSITY AND BIOGEOGRAPHY OF FRESHWATER CRUSTACEANS (DECAPODA: NATANTIA) FROM VANUATU, A COMPARISON WITH FIJI AND NEW CALEDONIA.
}

\author{
G. MARQUET (1), N. TAIKI (2), L. CHADDERTON (3), P. GERBEAUX (4)
}

(1) 18 rue des Papangues, Plateau Caillou, 97460 ST PAUL.

(2) Environment Unit, Private Mail Bag 063, PORT VILA, Vanuatu.

(3) Department of Conservation, P.O. Box 112, HAMILTON, New Zealand.

(4) Department of Conservation, Private Bag 701, HOKITIKA, New Zealand.

Reçu le 30 janvier 2002

Received 30 January, 2002

Accepté le 05 mars 2002

Accepted 05 March, 2002

\begin{abstract}
This is the first comprehensive study of freshwater decapoda crustaceans from Vanuatu. Of the nineteen species collected during this study, eighteen appear to be new records for the archipelago. However none of these species is endemic to Vanuatu, nine having a Pacific distribution and ten an Indo-Pacific distribution. Half of the species recorded were widely distributed in Vanuatu, whereas the others were more restricted. A comparison is made with the freshwater decapoda fauna of the two neighbouring archipelagoes namely, those of Fiji and New Caledonia, which have already been thoroughly surveyed.
\end{abstract}

Key-words : freshwater decapoda crustaceans, Atyidae, Palaemonidae, Goneplacidae, Grapsidae, Fiji, New Caledonia, Vanuatu.

\section{BIODIVERSITÉ ET BIOGÉOGRAPHIE DES CRUSTACÉS \\ D'EAU DOUCE (DECAPODA : NATANTIA) DU VANUATU. COMPARAISON AVEC FIDJI ET LA NOUVELLE-CALÉDONIE.}

\section{RÉSUMÉ}

Ceci est la première étude complète des crustacés d'eau douce du Vanuatu. Des 19 espèces récoltées au cours de cette étude, 18 ont été observées pour la première fois dans l'archipel. Cependant aucune de ces espèces n'est endémique du Vanuatu, neuf ayant une répartition spécifiquement pacifique et dix une répartition indo-pacifique. La moitié des espèces récoltées au Vanuatu étaient largement distribuées au sein de l'archipel alors que les autres avaient une répartition plus restreinte. Une comparaison a été effectuée avec les décapodes d'eau douce des deux archipels voisins, ceux de Fidji et de Nouvelle-Calédonie dont des études avaient déjà été faites.

Mots-clés : crustacés décapodes d'eau douce, Atyidae, Palaemonidae, Goneplacidae, Grapsidae, Fidji, Nouvelle-Calédonie, Vanuatu. 


\section{INTRODUCTION}

Vanuatu (Figure 1) is situated between $166^{\circ} \mathrm{E}-170^{\circ} \mathrm{E}$ longitude and $13^{\circ} \mathrm{S}-20^{\circ} \mathrm{S}$ latitude with an area of $12336 \mathrm{~km}^{2}$. Its nearest neighbours are the Solomon Islands (130 km to the north), New Caledonia (230 km southwest) and Fiji (800 km east). The archipelago consists of about 80 islands which lie on the edge of the Pacific plate. The islands are volcanic and coral reef in origin uplifted as the Pacific plate has been forced over the Indo-Australian plate. The two largest islands (Santo and Malakula) are also the oldest, appearing above sea level about 22 millions years ago. Pentecoste and Maewo were the next to appear (4-11 Myrs ago) with the remainder being formed during two major events less than 5 millions years ago (Table I) (GREEN et al., 1988).

The streams tend to be short and steep and generally lack low gradient alluvial floodplain reaches. Where these are present (e.g. Efate, Santo) the floodplain is usually heavily developed. Many streams are ephemeral or have sub surface flows during the dryer months, and some of the larger islands like Ambae do not contain rivers of any size or permanent flow in their lower reaches. There are few natural lakes of any size on any of the islands, except those associated with volcanic cones, and these typically do not have riverine connections to the sea.

In 1998, The Vanuatu Environment Unit began a 2 year national biodiversity project funded by the United Nation Environment Programme (UNEP). The unit set out to establish the distribution of dominant species of the fauna and flora across the 14 major islands in the archipelago with an emphasis on the freshwater communities due to paucity of information on these systems, environmental concerns and strong community interest. The information gathered is to be used to set priorities for biodiversity conservation in Vanuatu with regards to its obligations under the Convention on Biological Diversity.

Rapid biodiversity surveys were undertaken on a total of 14 large islands with well established freshwater ecosystems. The islands chosen were: Hiu, Mota Lava, Vanua Lava, Gaua Islands in Torba province, Santo in Sanma Province, Ambae, Maewo, Pentecost Island in Penama Province, Malakula in Malampa Province, Efate, Epi in Shefa Province and Aneityum, Erromango, Tanna in Tafea Province (Figure 1).

This paper presents the results of freshwater crustacean collections made as part of the national biodiversity survey, between 1998 and 1999. The freshwater crustacean fauna of Vanuatu is poorly understood and it appears that only Macrobrachium lar has previously been recorded (BAKER, 1929), whereas within the region, the fauna of Fiji (EDMONSON, 1935; EDMONSON, 1951; CHOY, 1983; CHOY, 1984a, b; CHOY, 1991), and New Caledonia (ROUX, 1926; KAMITA, 1967; HOLTHUIS, 1969; SHORT and MARQUET, 1998; MARQUET et al., 2001a; MARQUET et al., 2001b; CHOY and MARQUET, 2002; MARQUET, 2002) are more thoroughly studied.

The paper analyses results from the samples that were collected during these surveys (consisting of nineteen species from seven genera) and discusses their geographical distribution.

\section{MATERIAL AND METHODS}

Freshwater Crustacea were sampled using hand nets, baited traps and electrofishing. The latter was only available during part of the survey and unfortunately, out of the 14 islands surveyed, only five (Table I) were prospected using all three methods. Moreover, in the short time available for each island, only a small numbers of rivers were surveyed and for this paper specimens were examined from seven rivers in Efate Island, 
two rivers in Epi Island, five rivers in Pentecost Island, two rivers in Ambae Island and six rivers in Maewo Island. In addition, on the two largest and oldest islands of Vanuatu, Santo and Malakula, on two rivers each and only sampled with traps and hand nets. The most intensive sampling efforts have occurred on Efate Island and to a lesser extent Pentecost and Maewo Islands.

All collected crustacea were immediately preserved in $70 \%$ ethanol or $4 \%$ formalin.

The material examined is deposited in the collection of Rijksmuseum van Natuurlijke Historie, Leiden (RMNH) and Fisheries Department, Port Vila.

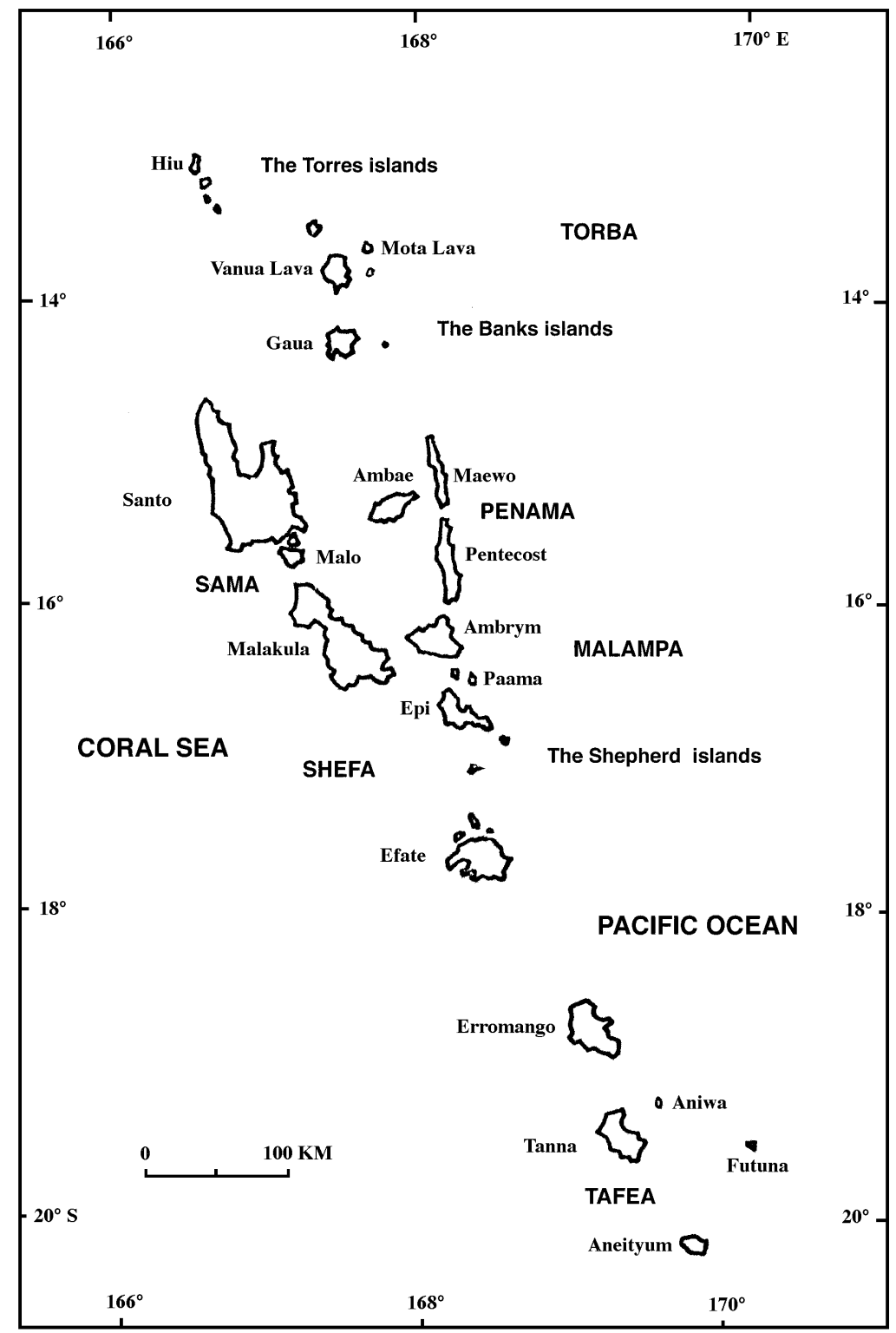

Figure 1

Map of Vanuatu.

Figure 1

Carte du Vanuatu. 


\section{Table I}

The islands of Vanuatu, their approximate age, size and survey techniques used in present study, and number of species recorded on each islands. EFM = electric fishing machine. ${ }^{*}=$ no material examined from these islands. Approximate age of oldest rock and size for Fiji and New Caledonia are also presented.

\section{Tableau I}

Les îles du Vanuatu, leur âge approximatif et leur taille ; les différentes techniques de prospection utilisées dans cette étude ; le nombre d'espèces recensées dans chaque île. $E F M=$ pêche électrique. ${ }^{*}$ = pas de matériel récolté dans ces îles. L'âge approximatif des plus vieilles roches et la superficie de Fidji et de la Nouvelle-Calédonie sont aussi fournies.

\begin{tabular}{|c|c|c|c|c|c|c|}
\hline Island & $\begin{array}{l}\text { Area } \\
\left(\mathrm{km}^{2}\right)\end{array}$ & $\begin{array}{c}\text { Age } \\
\text { (Myrs) }\end{array}$ & EFM & Traps & Hand nets & $\begin{array}{l}\text { Number of } \\
\text { species }\end{array}$ \\
\hline Hiu & 50 & & & + & + & * \\
\hline Mota lava & 35 & & & + & + & * \\
\hline Vanua lava & 331 & & & + & + & * \\
\hline Gaua & 330 & & & + & + & * \\
\hline Santo & 4010 & 22 & & + & + & 2 \\
\hline Ambae & 405 & 5 & + & + & + & 3 \\
\hline Maewo & 310 & 11 & + & + & + & 10 \\
\hline Pentecost & 500 & 11 & + & + & + & 11 \\
\hline Malakula & 2069 & 22 & & + & + & 4 \\
\hline Efate & 980 & $0-3$ & + & + & + & 17 \\
\hline Epi & 452 & $0-3$ & + & + & + & 2 \\
\hline Aneityum & 162 & $0-3$ & & + & + & * \\
\hline Erromango & 900 & $0-3$ & & + & + & * \\
\hline Tanna & 565 & & & + & + & * \\
\hline
\end{tabular}

\begin{tabular}{|c|c|c|c|}
\hline & & \\
\hline \multirow[b]{2}{*}{ Fiji } & & Size $\left(\mathrm{km}^{2}\right)$ & Age \\
\hline & Vonuticera & & 40 \\
\hline \multirow{2}{*}{\multicolumn{2}{|c|}{ New Caledonia }} & & 40 \\
\hline & & 19500 & $65+$ \\
\hline
\end{tabular}

\section{RESULTS}

\section{Taxonomy}

\section{ATYIDAE}

The present material brings the total number of species now known from Vanuatu to eight.

\section{Atyoida pilipes (Newport, 1847)}

Atya pilipes Newport, 1847: 160.

Type locality: Apia, Samoa.

Material examined: Efate (Creek Ai, Lololima River, Forari River, La Cressonière); Epi (Peteview, Voavingae); Pentecost (Lonbilitlit River, Bay Homo, Watmansabai River, Bwatnapni River, Walbongi River); Maewo (Vatmbilake River, Kenepe River, Nakurkura River, Mbeilata and Lowonolu Rivers). 

Polynesia.

Distribution: Pacific, extending from the Philippines and Indonesia to French

Remark: It is usually found in fast streams.

\section{Atyopsis spinipes (Newport, 1847)}

Atya spinipes Newport, 1847: 159.

Type locality: Philippine islands.

Material examined: Efate (Creek Ai, Forari River, Téouma River, La Cressonière), Pentecost (Lonbilitlit River, Bay Homo, Watmansabai River, Bwatnapni river, Walbongi river); Maewo (Vatmbilake River, Kenepe river, Nakurkura river, Mbeilata and Lowonolu Rivers).

Distribution: Pacific, extending from the Philippines and Indonesia to Samoa.

Remark: The habitat is similar to that of Atyoida pilipes although many specimens are found in much faster flowing waters with rocky substrate including waterfalls.

\section{Caridina brevicarpalis (De Man, 1892)}

Caridina brevicarpalis De Man, 1892: 397.

Type locality: Sulawesi (Indonesia).

Materiel examined: Efate (Tagabe River).

Distribution: Pacific (Philippines, Indonésie, Fiji).

Caridina longirostris (H. Milne Edwads, 1837)

Caridina longirostris H. Milne Edwards, 1837: 363.

Locality type: Oran (Africa).

Material examined: Efate (Lololima River, Forari River, Tagabe River, Téouma River); Pentecost (Lonbilitlit River, Bay Homo).

Distribution: Indo-West Pacific.

Remark: This species has a lowland and inland distribution.

Caridina serratirostris (De Man, 1892)

Caridina serratirostris De Man, 1892: 382.

Locality type: Flores, Indonesia.

Material examined: Efate (Tagabe River, Forari River).

Distribution: Indo-West Pacific.

Remark: This species has a lowland and coastal distribution. 


\section{Caridina typus (H. Milne Edwards, 1837)}

Caridina typus H. Milne Edwards, 1837: 363.

Locality type: Mauritius.

Material examined: Efate (La Cressonière); Pentecost (Bay Homo, Watmansabai River); Maewo (Mbeilata + Lowonolu Rivers); Ambae (Stream near Paul's Conservation).

Distribution: Indo-West Pacific.

Remark: This species has a lowland and inland distribution.

Caridina weberi (De Man, 1892)

Caridina weberi De Man, 1892: 371.

Locality type: Flores, Indonesia.

Material examined: Efate (Lololima River, Forari River, Creek Ai, Téouma River); Pentecost (Lonbilitlit River); Maewo (Mbeilata and Lowonolu Rivers).

Distribution: Indo-West Pacific.

Remark: This species occurs in vegetation, where water speed is slower and at higher elevations.

Caridina nilotica paeninsularis (Kemp, 1918)

Caridina brachydactyla peninsularis Kemp, 1918: 270.

Locality type: Penang, Malaysia.

Material examined: Efate (Forari River); Maewo (Nakurkura River).

Distribution: The varieties of $C$. nilotica are of dubious status. CHOY (1991) have reexamined specimens of EDMONDSON (1935) captured in Fiji: they belong to either $C$. nilotica or $C$. longirostris. The exact range of $C$. nilotica is not known due to the confused status of its taxonomic but it seems to have a wide Indo-Pacific distribution.

\section{PALAEMONIDAE} eight.

The present material brings the total number of species known from Vanuatu to Macrobrachium australe (Guérin-Méneville, 1838)

Palaemon australe Guérin-Méneville, 1838: 37.

Type locality: Tahiti, French Polynesia.

Material examined: Efate (Creek Ai, Forari River, Tagabe River, La Cressonière), Pentecost (Lonbilitlit River, Bay Homo, Walbongi River); Maewo (Nakurkura River).

Distribution: Indo-West Pacific.

Remark: This species occurs in the lower reaches of Rivers (MARQUET, 1991). 
Macrobrachium bariense (De Man, 1892)

Palaemon bariensis De Man, 1892: 496.

Type locality: Berit (Indonesia).

Materiel examined: Efate (Tagabe River); Malakula (Arap).

Distribution: Pacific (Indonesia, Philippines, Palau).

Macrobrachium gracilirostre (Miers, 1875)

Palaemon gracilirostre Miers, 1875: 343.

Type locality: Samoa.

Material examined: Efate (Creek Ai, Forari River, Téouma River, La Cressonière); Pentecost (Lonbilitlit River, Bay Homo, Watmansabai River, Bwatnapni); Maewo (Vatmbilake River, Kenepe River, Nakurkura river, Mbeilata + Lowonolu Rivers).

Distribution: Pacific (Riukiu islands, Moluccas, Lesser Sunda Islands, New Ireland, New Caledonia, Fiji, Samoa).

Remarks: M. gracilirostre is widespread in Vanuatu.

Macrobrachium lar (Fabricius, 1798)

Palaemon lar Fabricius, 1798: 402.

Type locality: India.

Material examined: Efate (Creek Ai, Tagabe River, La Cressonière); Pentecost (Lonbilitlit River, Bay Homo, Bwatnapni River, Walbongi River); Maewo (Vatmbilake River, Kenepe River, Nakurkura River, Mbeilata + Lowonolu Rivers); Ambae (Liasine stream, stream near Paul's Conservation).

Distribution: Indo-West Pacific.

Remarks: Macrobrachium lar is widespread in Vanuatu. It is ubiquitous in the Rivers of Vanuatu. It was also present in volcanic lakes that were connected to sea by streams as in the case of Lake Letas on Gaua Island.

Macrobrachium latidactylus (Thallwitz, 1891)

Palaemon latidactylus Thallwitz, 1891: 97.

Type-locality: northern Celebes.

Material examined: Santo (Jordan River); Malakula (Arap River).

Distribution: Pacific. This species has been reported from Malaya, Taiwan, Philippines and Indonesia. 
Macrobrachium latimanus (Von Martens, 1868)

Palaemon latimanus Von Martens, 1868: 44.

Type locality: Philippines.

Material examined: Efate (Forari River); Pentecost (Watmansabai River); Maewo (Mbeilata + Lowonolu Rivers); Ambae (Stream near Paul's Conservation).

Distribution: Indo-West Pacific.

Remarks: It occurs in the upper reach of Rivers (MARQUET, 1991).

Macrobrachium lepidactyloides (De Man, 1892)

Palaemon lepidactyloïdes De Man, 1892: 497.

Type-locality: « Raka-mbaha », Florès island, Indonesia.

Material examined: Efate (Téouma River).

Distribution: Pacific. It is known from Philippines, Indonesia and Fiji islands.

Macrobrachium placidulum (De Man, 1892)

Macrobrachium placidulus De Man, 1892: 489.

Type-locality: Celebes, Flores and Timor.

Material examined: Efate (Cressonière, Creek Ai, Téouma River); Epi (Voavingae River); Pentecost (Lonbilitlit River, Bay Homo, Bwatnapni River); Maewo (Vatmbilake River, Nakurkura River, Mbeilata and Lowonolu Rivers).

Distribution: Pacific. This species has been reported from Philippines, Indonesia, New Guinea, Palau and Fiji islands.

\section{GRAPSIDAE}

The present material brings the total number of species known from Vanuatu to three.

Varuna litterata (Fabricius, 1798)

Cancer litteratus Fabricius, 1798: 342.

Type locality: «In India Orientali ».

Material examined: Efate (Creek Ai, Tagabe River).

Distribution: Indo-West Pacific.

Remarks: This species occurs in the lower reaches of Rivers (MARQUET, 1991). 
Ptychognathus riedelii (A. Milne Edwards, 1868)

Gnathograpsus riedelii A. Milne Edwards, 1868: 182.

Type locality: Celebes (Indonesia).

Material examined: Pentecost (Lonbilitlit River), Malakula (Arap River).

Distribution: Andaman Islands, Indonesia.

Remarks: It is the first report from the Pacific Islands.

Utica gracilipes White, 1847

Utica gracilipes White, 1867: 86.

Type locality: Philippines.

Material examined: Efate (Forari River); Malakula (Arap River). Philippines).

Distribution: West Pacific (Sumatra, Flores, West Sumba, Solomon Island and

\section{DISCUSSION}

\section{Geographical distribution}

A total of nineteen species of freshwater crustaceans belonging to seven genera are now known from Vanuatu. All are new records except Macrobrachium lar (BAKER, 1929). The highest species diversity was recorded on Efate (Table I) and then Pentecost and Maewo Islands probably reflecting the more intensive electric fishing on these islands, and greater habitat diversity on the former. The small number of species collected from Santo and Malakula reflects the limited sampling effort and we would expect these islands to have at least the diversity of Efate. Species diversity is considerably lower than that recorded for Fiji (25 species) and New Caledonia (36 species). In contrast to Fiji and New Caledonia (Table II) where endemic species represent $12 \%$ and $36 \%$ of the total respectively, we have found no endemic species in Vanuatu.

The absence of endemic and lower species diversity recorded on Vanuatu probably results firstly on the weak and patchy sampling effort and secondly from the fact that the Archipelego is relatively a recent formation (ages assigned to the oldest islands of Vanuatu is about 23 million years (GREENE et al., 1988) whereas the oldest dated rocks of Fiji go back to 40 million years (RODDA, 1994) and New Caledonia (AUDLEY-CHARLES et al., 1981) results from the Gondwana break up over 65 million ago).

Indo-West Pacific species (52.6\%) are slightly more numerous (Table III and IV) than West Pacific species (47.4\%), whereas in Fiji and New Caledonia, Indo-West Pacific species (respectively $56 \%$ and $41 \%$ ) are more numerous than West Pacific species (respectively $32 \%$ and $23.5 \%$ ). This probably again reflects our sampling as Indo-West Pacific species are usually recorded in estuaries, shallow coastal stagnant water and caves, habitats rarely sampled in our surveys in Vanuatu. 
Table II

Freshwater crustaceans known from Vanuatu, Fiji and New Caledonia (+ = present; - = absent).

Tableau II

Les crustacés d'eau douce du Vanuatu, Fidji et de Nouvelle-Calédonie (+ = présent, - = absent).

\begin{tabular}{|c|c|c|c|c|}
\hline Family & Species & $\begin{array}{c}\text { Fiji } \\
\text { Atyidae: CHOY, 1983; } \\
\text { CHOY, 1984a; CHOY, 1991 } \\
\text { Grapsidae: EDMONSON, 1951 } \\
\text { Palaemonidae: CHOY, 1984b }\end{array}$ & $\begin{array}{c}\text { New Caledonia } \\
\text { Atyidae: CHOY and MARQUET, } 2002 \\
\text { Goneplacidae: (MARQUET et al., 2001b) } \\
\text { Grapsidae: PRETZMANN, 1968 } \\
\text { Hymenosomatidae: NG and RICHER DE FORGES,1996 } \\
\text { Palaemonidae: SHORT and MARQUET, 1998; MARQUET, } 2002\end{array}$ & $\begin{array}{c}\text { Vanuatu } \\
\text { (present study) }\end{array}$ \\
\hline \multirow{19}{*}{ Atyidae } & Antecaridina lauensis & + & + & - \\
\hline & Atyoida pilipes & + & + & + \\
\hline & Atyopsis spinipes & + & + & + \\
\hline & Paratya bouvieri & - & endemic & - \\
\hline & P. caledonica & - & endemic & - \\
\hline & P. intermedia & - & endemic & - \\
\hline & P. typa & - & endemic & - \\
\hline & P. sp1 & - & endemic & -- \\
\hline & P. sp2 & - & endemic & - \\
\hline & Caridina brevicarpalis & + & - & + \\
\hline & C. devaneyi & endemic & - & - \\
\hline & \begin{tabular}{|l|} 
C. fijiana \\
\end{tabular} & endemic & - & - \\
\hline & C. imitatrix & - & endemic & - \\
\hline & C. japonica & + & - & - \\
\hline & C. leucosticta & - & + & - \\
\hline & C. longirostris & + & + & + \\
\hline & C. gracilirostris & - & + & - \\
\hline & C. nilotica & + & + & + \\
\hline & C. novaecaledoniae & - & endemic & - \\
\hline
\end{tabular}




\begin{tabular}{|c|c|c|c|c|}
\hline \multirow{7}{*}{ Atyidae } & C. nudirostris & endemic & - & - \\
\hline & C. serratirostris & + & + & + \\
\hline & C. typus & + & + & + \\
\hline & C. vitiensis & + & + & - \\
\hline & C. weberi & + & + & + \\
\hline & C. sp1 & - & endemic & - \\
\hline & C. sp2 & - & endemic & - \\
\hline Goneplacidae & Australocarcinus kanaki & - & endemic & - \\
\hline \multirow{3}{*}{ Grapsidae } & Ptychognathus riedelii & - & - & + \\
\hline & Utica gracilipes & - & - & + \\
\hline & Varuna litterata & + & + & + \\
\hline Hymenosomatidae & Odiomaris pilosus & - & endemic & - \\
\hline \multirow{16}{*}{ Palaemonidae } & Macrobrachium aemulum & - & + & - \\
\hline & M. australe & + & + & + \\
\hline & M. bariense & - & - & + \\
\hline & M. caledonicum & - & endemic & - \\
\hline & M. equidens & + & + & - \\
\hline & M. gracilirostre & + & + & + \\
\hline & M. grandimanus & + & + & - \\
\hline & M. lar & + & + & + \\
\hline & M. latidactylus & - & - & + \\
\hline & M. latimanus & + & + & + \\
\hline & M. lepidactyloides & + & - & + \\
\hline & M. microps & - & + & - \\
\hline & M. placidulum & + & + & + \\
\hline & Palaemon concinnus & + & + & - \\
\hline & P. debilis & + & + & - \\
\hline & Total & 25 & 36 & 19 \\
\hline
\end{tabular}


Table III

Geographical distribution of freshwater crustaceans reported from Vanuatu.

Tableau III

Répartition géographique des crustacés d'eau douce recensés du Vanuatu.

\begin{tabular}{|c|c|c|}
\hline Species & $\begin{array}{l}\text { Geographical } \\
\text { distribution }\end{array}$ & $\begin{array}{c}\text { Distribution within } \\
\text { Vanuatu }\end{array}$ \\
\hline \multicolumn{3}{|l|}{ Genus: Atyoida } \\
\hline A. pilipes & West Pacific & Efate, Epi, Pentecost, Maewo \\
\hline \multicolumn{3}{|l|}{ Genus: Atyopsis } \\
\hline A. spinipes & West Pacific & Efate, Pentecost, Maewo \\
\hline \multicolumn{3}{|l|}{ Genus: Caridina } \\
\hline C. brevicarpalis & West Pacific & Efate \\
\hline C. longirostris & Indo-West Pacific & Efate, Pentecost \\
\hline C. nilotica peninsularis & Indo-West Pacific & Efate, Maewo \\
\hline C. serratirostris & Indo-West Pacific & Efate \\
\hline C. typus & Indo-West Pacific & Efate, pentecost, Maewo, Ambae \\
\hline C. weberi & Indo-West Pacific & Efate, Pentecost, Maewo \\
\hline \multicolumn{3}{|l|}{ Genus: Macrobrachium } \\
\hline M. australe & Indo-West Pacific & Efate, Pentecost, Maewo \\
\hline M. bariense & West Pacific & Santo, Malekula, Efate \\
\hline M. gracilirostre & West Pacific & Efate, Pentecost, Maewo \\
\hline M. lar & Indo-West Pacific & Efate, pentecost, Maewo, Ambae \\
\hline M. latidactylus & West Pacific & Santo, Malekula \\
\hline M. latimanus & Indo-West Pacific & Efate, pentecost, Maewo, Ambae \\
\hline M. lepidactyloides & West Pacific & Efate \\
\hline M. placidulum & West Pacific & Efate, Epi, pentecost, Maewo \\
\hline \multicolumn{3}{|l|}{ Genus: Ptychognathus } \\
\hline$P$. riedelii & Indo-West Pacific & Pentecost, Malakula, \\
\hline \multicolumn{3}{|l|}{ Genus: Varuna } \\
\hline Varuna litterata & Indo-West Pacific & Efate \\
\hline \multicolumn{3}{|l|}{ Genus: Utica } \\
\hline Utica gracilipes & West Pacific & Malakula, Efate \\
\hline
\end{tabular}

Nine species (47.4\%) seem to be widely distributed within Vanuatu (Table III): Atyoida pilipes, Atyopsis spinipes, Caridina typus, C. weberi, Macrobrachium australe, M. gracilirostre, M. lar, M. latimanus and M. placidulum, consistent with their Indo-Pacific or West Pacific distributions.

All these species are also present in Fiji and New Caledonia (Table II), although in New Caledonia, neither $M$. gracilirostre nor $M$. placidulum appear common. For instance (MARQUET, 2002) records only a single specimen of $M$. gracilirostre from one river in New Caledonia and the first specimens of $M$. placidulum were only recently recorded from another New Caledonia river by one of us (MARQUET et al., 2001b).

Ten species (53.6\%) seem to have restricted distribution (Table III): Caridina longirostris, C. brevicarpalis, C. nilotica paeninsularis, C. serratirostris, Varuna litterata, Macrobrachium lepidactyloides, $M$. latidactylus, $M$. bariense, Ptychognathus riedelii and Utica gracilipes. 
Caridina longirostris and C. nilotica peninsularis (Table III) were found only in two islands, respectively in (Efate, Pentecost) and (Efate, Maewo). The former is common and widespread in Fiji and New Caledonia (Table II). The varieties of C. nilotica are of dubious status. C. nilotica is common and widespread in Fiji (CHOY, 1991) and whereas it is rarely recorded in New Caledonia (CHOY and MARQUET, 2002).

Caridina brevicarpalis, Caridina serratirostris, Varuna litterata and Macrobrachium lepidactyloides are present only on Efate. However, we predict that these Indo-Pacific or Pacific species will have a wider distribution in Vanuatu. Their presence in Vanuatu helps to explain the Fijian records (Table II). In New Caledonia among these four species, M. lepidactyloides and Caridina brevicarpalis are absent (Table II).

Macrobrachium latidactylus and $M$. bariense are present only in the two largest and oldest islands, Santo and Malakula, suggesting these islands are likely to contain a similar or greater diversity of crustacea than Efate, as well as potentially additional new species for Vanuatu. These two islands are also most likely to contain potential endemic species. Ptychognathus riedelii was only present on Pentecost and Efate and Utica gracilipes on Efate and Malakula. These four species do not appear to occur in Fiji and New Caledonia (Table II). These records represent an eastward extension of the distribution of these species' and suggest a potential link to the Crustacean fauna of the Solomon Islands and Papua New Guinea.

At least ten species (Palaemon concinnus, P. debilis, Antecaridina lauensis, Macrobrachium aemulum, M. equidens, M. grandimanus, M. microps, C. japonica, C. vitiensis and $C$. gracilirostris) with relatively widespread Pacific distribution were not recorded in Vanuatu (Table II).

Palaemon concinnus, P. debilis, Macrobrachium equidens, M. grandimanus and Antecaridina lauensis occur in Fiji and New Caledonia. The first three species are restricted to estuaries and shallow coastal stagnant waters. A. lauensis is an anchialine species. M. grandimanus occurs in the river where tidal influence exist, or in caves. These habitat were not surveyed in Vanuatu.

M. aemulum is a very common species widespread in New Caledonia (MARQUET, 2002) and in French Polynesia (MARQUET, 1991). This species has not been recorded in Vanuatu or Fiji, which raises the question of the taxonomic status of the specimens from French Polynesia and New Caledonia. Is it the same species?

Caridina japonica only occurs in Fiji and no specimens have been captured in Vanuatu and New Caledonia. C. japonica was captured in one island in Fiji by CHOY (1991). This species seems to have an unusually restricted distribution in our study area, though it has a wide Indo-Pacific distribution (Madagascar and Japan), although further sampling within Vanuatu may be illiminating.

Caridina vitiensis is widely distributed in the Indo-Pacific (Sri Lanka, New Guinea, Solomon islands) and is present in Fiji and New Caledonia (Table II) although it is not common in either area. For example EDMONSON (1935) did not collect any from Fiji in 1933. Its low abundance in these areas may explain is apparent absence, to date, from Vanuatu.

Caridina gracilirostre is also widely distributed in the Indo-Pacific (Madagascar, Indonesia) but was captured in New Caledonia in only one river (MARQUET, 2002).

Finally Macrobrachium microps occurs only in New Caledonia. This species has not been recorded in Vanuatu or Fiji. It is an anchialine species, occupying habitats that were not surveyed in Vanuatu. 


\section{Table IV}

List of sampling sites and crustacean species collected at each.

\section{Tableau IV}

Liste des sites prospectés et des espèces de crustacés récoltées pour chaque site.

\begin{tabular}{|c|c|c|c|c|}
\hline $\begin{array}{l}\text { Sampling } \\
\text { sites }\left(n^{\circ}\right)\end{array}$ & Islands & Rivers & $\begin{array}{l}\text { Date of } \\
\text { collection }\end{array}$ & Species collected \\
\hline 1 & Efate & creek Ai & 19-06-1998 & $\begin{array}{c}\text { Atyoida pilipes; Atyopsis spinipes; } \\
\text { Macrobrachium australe; M. gracilirostre; M. lar }\end{array}$ \\
\hline 2 & Efate & Lololima & $20-06-1998$ & Atyoida pilipes; Caridina longirostris; $C$. weberi \\
\hline 3 & Efate & Forari River & 04-11-1998 & $\begin{array}{c}\text { Atyoida pilipes; Atyopsis spinipes; } \\
\text { Caridina nilotica paeninsularis; C. longirostris; } \\
\text { C. weberi }\end{array}$ \\
\hline 4 & Efate & creek Ai & 06-11-1998 & $\begin{array}{c}\text { Atyoida pilipes; Atyopsis spinipes; Caridina weberi; } \\
\text { Macrobrachium gracilirostre; M. lar, M. placidulum; } \\
\text { Varuna litterata }\end{array}$ \\
\hline 5 & Efate & Tagabe & 06-11-1998 & $\begin{array}{l}\text { Caridina longirostris; C. serratirostris; } \\
\text { Macrobrachium australe; M. lar }\end{array}$ \\
\hline 6 & Efate & Téouma & 09-11-1998 & $\begin{array}{c}\text { Atyopsis spinipes; Caridina longirostris; C. weberi; } \\
\text { Macrobrachium gracilirostre; M. lepidactyloides; } \\
\text { M. placidulum }\end{array}$ \\
\hline 7 & Epi & Peteview & $23-06-1998$ & Atyoida pilipes \\
\hline 8 & Epi & Voavingae & $24-06-1998$ & Atyoida pilipes; Macrobrachium placidulum \\
\hline 9 & Pentecost & Lonbilitlit & 08-10-1998 & $\begin{array}{c}\text { Atyoida pilipes; } \text { Atyopsis spinipes; } \\
\text { Caridina longirostris; C. weberi; } \\
\text { Macrobrachium australe; M. gracilirostre; M. lar, } \\
\text { Macrobrachium placidulum; Ptychognathus riedelii }\end{array}$ \\
\hline 10 & Pentecost & Bay Homo & 09-10-1998 & $\begin{array}{l}\text { Atyoida pilipes; Atyopsis spinipes; } \\
\text { Caridina longirostris; C. typus }\end{array}$ \\
\hline 11 & Pentecost & Watmansabai & 12-10-1998 & $\begin{array}{l}\text { Atyoida pilipes; Atyopsis spinipes; C. typus; } \\
\text { Macrobrachium gracilirostre; } M \text {. latimanus }\end{array}$ \\
\hline 12 & Pentecost & Bwatnapni & $14-10-1998$ & $\begin{array}{c}\text { Atyoida pilipes; Atyopsis spinipes; } \\
\text { Macrobrachium gracilirostre; M. Iar, M. placidulum }\end{array}$ \\
\hline 13 & Pentecost & Walbongi & $16-10-1998$ & $\begin{array}{c}\text { Atyoida pilipes; Atyopsis spinipes; M. australe; } \\
\text { M. lar }\end{array}$ \\
\hline 14 & Ambae & Liasine & $20-10-1998$ & Macrobrachium lar, M. latimanus \\
\hline 15 & Ambae & near Paul's Conservation & $26-10-1998$ & Caridina typus; Macrobrachium lar, M. Iatimanus \\
\hline 16 & Maewo & Vatmbilake & 24-10-1998 & $\begin{array}{c}\text { Atyoida pilipes; Atyopsis spinipes; } \\
\text { Macrobrachium gracilirostre; } M \text { M. lar, } M \text {. placidulum }\end{array}$ \\
\hline 17 & Maewo & Vatmbilake & $25-10-1998$ & $\begin{array}{l}\text { Atyoida pilipes; Atyopsis spinipes; } \\
\text { Macrobrachium gracilirostre }\end{array}$ \\
\hline 18 & Maewo & Kenepe & $26-10-1998$ & $\begin{array}{c}\text { Atyoida pilipes; Atyopsis spinipes; } \\
\text { Macrobrachium gracilirostre; M. Iar, M. placidulum }\end{array}$ \\
\hline 19 & Maewo & Nakurkura & $26-10-1998$ & $\begin{array}{c}\text { Atyoida pilipes; Atyopsis spinipes; } \\
\text { Caridina nilotica paeninsularis; } \\
\text { Macrobrachium australe; } M . \text { gracirostre; M. lar, } \\
\text { M. placidulum } \\
\end{array}$ \\
\hline 20 & Maewo & Mbeilata +Lowonolu & 29-10-1998 & $\begin{array}{c}\text { Atyoida pilipes; Atyopsis spinipesCaridina typus; } \\
\text { C. weberi; M. gracilirostre; M. lar, M. latimanus; } \\
\text { M. placidulum }\end{array}$ \\
\hline 21 & Santo & Jordan & $06-05-1999$ & Macrobrachium latidactylus; Utica gracilipes \\
\hline 22 & Santo & Buvo & $08-05-1999$ & Macrobrachium bariense; Utica gracilipes \\
\hline 23 & Malekula & Arap & $11-05-1999$ & Macrobrachium bariense;Utica gracilipes \\
\hline 24 & Malekula & Arap & 12-05-1999 & Macrobrachium latidactylus; Ptychognathus riedelii \\
\hline 25 & Efate & Tagabe & 29-11-1999 & $\begin{array}{l}\text { Caridina brevicarpalis; Caridina longirostris; } \\
\text { C. serratirostris; Macrobrachium bariense; } \\
\text { M. australe; M. Iar, M. placidulum; Varuna litterata }\end{array}$ \\
\hline 26 & Efate & Lololima & $01-12-1999$ & Caridina weberi; Macrobrachium lar \\
\hline 27 & Efate & La Cressonière & 01-12-1999 & $\begin{array}{c}\text { Atyoida pilipes; Atyopsis spinipes; Caridina typus; } \\
\text { Macrobrachium australe; M. gracilirostre; M. lar, } \\
\text { M. placidulum }\end{array}$ \\
\hline 28 & Efate & Forari & 01-12-1999 & $\begin{array}{l}\text { Caridina longirostris; C. serratirostris; } \\
\text { Macrobrachium australe; Utica gracilipes }\end{array}$ \\
\hline
\end{tabular}


The limited crustacean community recorded from Vanuatu is probably a reflection of the low level of sampling (reliance on traps and nets) and young age of the archipelago. We predict that a number of Pacific species known to be present in neighbouring New Caledonia and Fiji are likely to be present in Vanuatu, including some species presently considered to be endemics to those areas. Additional intensive survey work should be undertaken on Santo and Malakula, as these are the oldest, and largest islands and contain a greater diversity of habitats with the highest chance of containing new records and potentially endemic species. Erromango is also a priority for intensive survey work as it is the largest island close to New Caledonia with permanent streams. Estuarine habitats, caves and lagoons also require as they have not been sampled to date. Only when a more thorough inventory and description of the distribution of these species is completed, will it be possible to identify potential indicator species (of habitat degradation) and communities, or taxa that are priorities for greater protection.

\section{ACKNOWLEDGMENTS}

We thank Donna Kalfatak, Russel Nari and Jenny Whyte of the Vanuatu Environment Unit, and the Provincial authorities for facilitating the research done in Vanuatu. The biodiversity surveys were funded by a grant from United Nations Environment Programme. As part of this project two of us (LC, PG) were seconded to train Vanuatu Environment Unit staff in general freshwater survey techniques. The New Zealand Ministry of Foreign Affairs and Trade (MFAT) funding the costs of this secondment and the New Zealand Department of Conservation (DoC) provided three staff at no cost. Thanks to Chris Richmond (DoC) and Roger Cornforth (MFAT) for facilitating the secondment, and for Chris's assistance and input into survey work on Epi and Efate. We wish to express our gratitude to Professor L.B. Holthuis (Rijksmuseum van Natuurlijke Historie, Leiden, Netherlands) for confirmation of the species identified. Our special thanks go to Brian Philipps, Katrina Sali and the Fisheries Officers for their invaliable assistance and company in the field.

\section{REFERENCES}

AUDLEY-CHARLES M.G., HURLEY A.M., SMITH A.G., 1981. Continental movements in the Mesozoic and Cenozoic. In : «Wallace's Line and Plate Tectonics ». WHITMORE T.C. (ed.). Clarendon Press. Oxford, 9-23.

BAKER J.R., 1929. Man and animals in the New hebrides. London, George ROULEDGE \& Sons (Eds.), 200 p.

CHOY S.C., 1983. Caridina fijiana n. sp. (Decapoda: Atyidae) from Nadarivatu, Fiji. New Zealand Journal of Zoology, 10, 147-150.

CHOY S.C., 1984a. A new atyid shrimp, Caridina nudirostris sp. nov. (Decapoda, Natantia, Atyidae) from Nadrau Plateau, Fiji. Crustaceana, 46 (3), 288-294.

CHOY S.C., 1984b. On the freshwater Palemonid Prawns from the Fiji islands (Decapoda, Caridea). Crustaceana, 47 (3), 269-277.

CHOY S.C., 1991. The Atyid shrimps of Fiji with description of a new species. Zoologische Mededelingen., 65, 343-362.

CHOY S.C., MARQUET G., 2002. Biodiversity and Zoogeography of Atyid Shrimps (Crustacea: Decapoda: Natantia) of New Caledonia. Zoologia Neocaledonica, ORSTOM, sous presse.

EDMONSON C.H., 1935. Atyidae of southern Polynesia. Occasionnal Papers of Bernice P. Bishop Museum, 11 (3), 1-19, figs. 1-6.

EDMONSON C.H., 1951. Some central pacific crustaceans. Occasionnal Papers of Bernice P. Bishop Museum, 11 (3), 183-243, figs. 1-38.

GREENE H.G., MACFARLANE A., WONG F.L., 1988. Geology and Offshore Resources of Vanuatu - Introduction and Summary. In : GREENE H.G. and WONG F.L. (Eds.), 
1988. Geology and offshore resources of Pacific island arcs -Vanuatu region, Circum- Pacific Council for Energy and Mineral Resources. Earth Science Series, 8, Houston, Texas, 1-25.

KAMITA T., 1967. Some shrimps and prawns from New Caledonia. Bulletin of the Osaka Museum of National History, 20, 1-10, pl. 1.

HOLTHUIS L.B., 1969. Etudes hydrobiologiques en Nouvelle-Calédonie (Mission 1965 du Premier institut de Zoologie de l'Université de Vienne. IX. The freshwater shrimps of New Caledonia. Cahiers de l'O.R.S.T.O.M., Série Hydrobiologie, 3 (2), 87-108, figs. 1-4.

MARQUET G., 1991. Freshwater Crustaceans of French Polynesia: Taxonomy, Distribution and Biomass (Decapoda). Crustaceana, 61 (2), 125-140.

MARQUET G., 2002. Distribution of the freshwater Palaemonid Prawns (Crustacea: Decapoda: Natantia) in New Caledonia. Zoologia Neocaledonica, ORSTOM, sous presse.

MARQUET G., KEITH P., VIGNEUX E., 2001a. Rapport intermédiaire sur les crustacés et les poissons d'eau douce de la province sud. Service de l'Environnement de la Province Sud, $82 \mathrm{p}$.

MARQUET G., KEITH P., VIGNEUX E., 2001b. Inventaire des crustacés et des poissons d'eau douce de la Province Nord. Service de l'Environnement de la Province Nord, $88 \mathrm{p}$.

NG P.K.L., RICHER DE FORGES B., 1996. The Hymenosomatidae (Crustacea: Decapoda: Brachyura) of New Caledonia, with descriptions of two new genera and two new species. Memoirs of Queensland Museum, 39 (2), 263-276.

PRETZMANN G., 1968. Etudes hydrobiologiques en Nouvelle-Calédonie. VII. Brachyures. Cahiers de l'O.R.S.T.O.M., Série Hydrobiologie, 2 (2), 3-7.

RODDA P., 1994. Geology of Fiji. In : STEVENSON A.J., HERZER R.H. and BALANCE P.F. (Eds.). Geology and Submarine Resources of the Tonga-Lau-Fiji Region. SOPAC Technical Bulletin, 8, 131-151.

ROUX J., 1926. Crustacés décapodes d'eau douce de la Nouvelle-Calédonie. In : SARASIN F. et ROUX J., Nova Caledonia, 4 (2), 181-240, figs. 1-56.

SHORT J.W., MARQUET G., 1998. New records of freshwater Palaemonidae (Crustacea, Decapoda) from New Caledonia. Zoosystema, 20 (2), 401-410. 